\title{
An environment for integration?: Climate change, sustainable development and Europe's external identity
}

\author{
E. Boydell \\ Fenner School of Environment, The Australian National University, Acton ACT 0200, Canberra, \\ Australia
}

\begin{abstract}
Sustainable Development has been evolving as a guiding principle in European politics, and Europe has demonstrated strong leadership in climate change mitigation. This essay explores the sustainable development discourse in Europe and how it has driven unified European Union action on climate change. As climate change is one of the biggest long-term problems facing humanity, Europe's proactive role in international negotiations has been of crucial importance to secure international agreements. In spite of the complexity of the European Union decision making process, member states have demonstrated a precedent of working collaboratively to achieve strong cuts in greenhouse gas emissions. Support and re-enforcement has come from many levels. Sustainable Development discourse and the urgency created by climate change has been a cohesive force in internal EU politics and a part of Europe's international agenda. As Europe leads by example in climate change mitigation, sustainable development becomes part of its external identity. The EU will play a crucial role in forming a successful outcome at the $15^{\text {th }}$ Conference of the Parties of the UN Framework Convention on Climate Change. In the face of Economic Concern, the EU must re-affirm and demonstrate its commitment to unity, and ambition for a sustainable future.
\end{abstract}

\section{INTRODUCTION}

Over the last two decades, the Europe has positioned itself as a global sustainability leader. The European Union (EU) plays a significant and powerful role in international environmental policy, continuing to demonstrate leadership in climate change mitigation. In this essay, I examine how cooperation and cohesion in response to global climate change (GCC) has shaped EU external policy identity. I begin by examining the discourse of sustainable development (SD) as a cohesive force in the EU, and outline the mechanisms for the EU's solidity in the negotiation and domestic implementation of the United Nations Framework Convention on Climate Change (UNFCCC) and the Kyoto Protocol. I then argue that EU action on GCC, grounded in a European understanding of sustainability, contributes to the external policy identity of the EU as a normative force in global affairs. Recent developments - including high level environmental diplomacy, the announcement of strong Greenhouse Gas (GHG) mitigation targets and further integration of sustainability into $\mathrm{EU}$ activity through the Lisbon Treaty-raise the pressure on the EU to be successful as a long-term SD leader. However, the short-term success of EU's normative power will face a critical test in negotiating a post-2012 climate agreement in challenging economic times.

\section{SUSTAINABILITY AND SHARED VISION}

Unity in European external policy identity has been facilitated by a discourse of sustainable development. Dryzek (2005: 5, 19) identifies discourse as a "shared way of apprehending the world", common sets of ontology, assumptions, agents and metaphors. The SD discourse is based on a general understanding that environmental protection can be compatible with economic and social development, and is essential to ensuring the long term viability of economic and social systems (Dryzek 2005: 16; Kronsell 1997: 118). There is no consensus on what SD and sustainability actually are, and herein lies the power of the discourse in European (and global) politics and society.

The plurality of understanding surrounding sustainable development is partly responsible for the power of the discourse; in Europe it has evolved as a political force that can gather support from a multitude of actors (Sneddon et al. 2006). Environmental protection has been a top public priority in the Eurobarometer survey ${ }^{1}$ for over 20

\footnotetext{
${ }^{1}$ The Eurobarometer is co-ordinated by the Directorate General Communications on the request of the European Commission and the European Parliament. It samples individuals aged 15 and over in member countries and three candidate states.
} 
years (Oberthür and Roche Kelly 2008; Schreurs and Tiberghien 2007). There has been a continuous and increasing level of media attention surrounding environmental issues, including GCC. This concern is reflected in the European Parliament, with Green political groups having had a significant prominence (Bainbridge 2002: 422). The plurality in understandings of SD means that these concerns and priorities can be integrated with the economic growth and integration paradigm which underlies EU activity (Sbragia and Stolfi 2008: 132). The discourse allows for political reconciliation of the assertive pro-environment stance of Finland and Sweden with the national economic development priorities of Spain and the newer EU members. It has shifted environmental regulation toward working with, rather than against industry (Kronsell 1997: 119 ), and has even led to the (previously unlikely) partnerships between business interest groups and environmental NGOs (Dryzek 2005: 152) ${ }^{2}$.

Sustainable development was enshrined in EU's identity by the 1997 Amsterdam Treaty (Dinan 2005: 366). While the Environment Commissioner and the Directorate-General Environment takes leadership on environmental protection, integrated SD discourse has led to recognition under the Article 130r (2) that 'Environmental protection must be integrated into the definition and implementation of other community policies" (Delreux 2006). Under the 2001 Treaty of Nice, competence on most environmental issues is shared between the European Community (EC) and EU member states - meaning that most environment-related decisions can be made through qualified majority voting in the Council. (Schreurs and Tiberghien 2007). The protection of the environment has become a concern central to European identity, and $\mathrm{SD}$ is an overarching objective of the EU (e.g. Article 2, Treaty of the European Union) (Vogler and Stephan 2007). Global climate change presents the single largest threat to SD concerns and objectives, along with its severe social, economic and security consequences across a variety of scales (Parry et al. 2007). The 2008 Eurobarometer survey revealed that Europeans believe GCC to be the second most serious global problem after the related issue of "poverty, the lack of food and drinking water" (TNS Opinion and Social 2008: 5). Within the discourse of $\mathrm{SD}$, the EU its member states and

\footnotetext{
${ }^{2}$ The campaign partnership between the World Business Council for Sustainable Development and Environmental NGO Greenpeace at the 2002 World Summit for Sustainable Development is a prominent example
}

citizens have had a continued interest in preventing dangerous climate change ${ }^{3}$.

In October 1990, the European Community (EC) Ministers of Energy and the Environment announced that GHG emissions of the EC were to be stabilised at 1990 levels by the Year 2000, mirroring the independent commitments made by the Dutch, German, Danish and Austrian governments in the preceding 12 months (Huber 1997: 143; Schreurs and Tiberghien 2007). With this collective target and sustainability discourse, the $\mathrm{EU}^{4}$ entered into international GCC negotiations leading up to UNFCCC, which opened for signature at the 1992 United Nations Conference on Environment and Development (UNCED) in Rio de Janeiero. The EC and member states were among the first signatories. The cohesive approach demonstrated in the early 1990s continues; it remains central to GCC mitigation in Europe and the role of the $\mathrm{EU}$ in international GCC negotiations. Alone, member states have relatively small carbon footprints and mixed capacity to mitigate emissions. The EU becomes a multiplier for the power of individual states in international negotiations - having a total impact "greater than the sum of its parts" (Peterson 2008:204). In 2004, the EU accounted for $14.7 \%$ of global GHG emissions (United Nations Statistics Division 2007). Reduction in the EU's collective emissions has a global impact. The EU also has a market of 500 million consumers, 40 percent more than the USA (Peterson 2008), and is the biggest provider of aid to developing countries (European Communities, 2008). As both an intergovernmental and supranational entity, the EU has the internal capacity to make these reductions, and a significant capacity to influence other countries to do the same.

\section{MECHANISMS FOR COHESION}

The EU has maintained a unified climate change mitigation strategy and cohesive negotiating position at the UNFCCC despite significant institutional barriers. The European policy making structures and

\footnotetext{
${ }^{3}$ The EU has accepted dangerous climate change as mean global temperature increase greater than two degrees above a pre-industrial baseline (1.4 degrees above the current temperature). Stabilising atmospheric $\mathrm{CO}_{2}$ concentration at less than 450 parts per million will reduce the probability of this occurring to $50 \%$ (Parry et al., 2007)

${ }^{4}$ In 1990 , negotiations were carried out by the European Economic Community and its 15 member states.
} 
mechanisms for legal personality in an international setting are complex and unique. The European Union, as an entity, does not always have a supranational legal personality - $\mathrm{a}$ power to represent EU member states at an international level and accede to international agreements. While the European Community "pillar" of the EU (represented by the European Commission-the EU's multinational civil service) does have legal personality, the international agreements that the Commission negotiates have to be ratified by the European Council, which consists of ministers from member states (Delreux 2006). Furthermore, while environmental policy falls under the competence of the Commission, member states remain largely responsible for energy and transportation, sectors critical to climate change response (Lacasta et al. 2007: 215). This mixed competence means that the EU negotiation and accession to international agreements is conducted jointly by the European Communities (represented by the Commission), the Council, and individual member states (Oberthür and Roche Kelly 2008). Therefore, a cohesive position is necessary to produce a binding agreement (Delreux 2006).

Responsibility for forming cohesion between the EC/member state positions lies with the Presidency of the European Council, which consists of ministers from member countries. The president is assisted by an ad hoc Climate Working Group of environmental ministers from the council (Delreux 2006; Schreurs and Tiberghien 2007). The President has the power to add international agreements to the aquis communautaire, making them EU law. The SD discourse is evident in numerous aspects of this process. Delreux (2006) and Lacasta et al. (2007) note that proactive policy entrepreneurship under the 1997 Dutch presidency was critical to the advancement of the sustainability and climate change agenda, and the development and articulation of an EU position leading up to Kyoto-indicating that the EU position may have been considerably weaker under another leadership. However, Schreurs and Tiberghien (2007) argue that the multiple levels of EU leadership, unified by the SD discourse, allowed for the incorporation of a greater level of public engagement, and ultimately support, for the EU's position on GCC. The Commission has used the environmental and climate change agenda as a focal point for integration, building consensus, unity and international leadership with much greater success than the Common Foreign and Security policy (Oberthür and Roche Kelly 2008; Schreurs and Tiberghien, 2007). In a time where confidence has been reduced in other aspects of European integration, SD and GCC have become drivers to internally promote the power of a cohesive European response to domestic and global issues.

\section{Climate Change In THE EU'S BROADER POLICY IDENTITY}

The successes of the EU's unified and cohesive approach to GCC complement a broader foreign policy identity. The EU can be regarded as a "normative power" in global affairs, acting primarily through ideals and values rather than military force (Falkner 2006). "Leadership by example" is a critical part of this power and identity, and the EU must demonstrate that aggressive emission reductions are possible in order to maintain integrity as a GCC leader (Oberthür and Roche Kelly 2008). Under the Kyoto Protocol, the EU committed to an $8 \%$ reduction of GHG emissions from 1990 levels by 2012. The EU negotiated a unique burdensharing approach to collectively reach this target across the 15 states that were members of the EU (EU-15) at the time of ratification, known as the "EU bubble". Their approach has embodied the principles of Equity and Common but Differentiated Responsibilities central to the UNFCCC - that countries, based upon their historic emissions and present capabilities have different levels of mitigation responsibility (Schreurs and Tiberghien 2007; Vogler and Bretherton 2006). Under the "EU bubble", the bulk of emissions reductions have been provided by the UK (through the transition from coal to natural gas in the energy sector) and Germany (through the de-industrialisation of the east, and investment in renewable energy), which has allowed Spain, Portugal and Greece to increase national emissions as they achieve economic development outcomes.

The EU bubble has also made exemplary use of market-based instruments for mitigation, including the Emissions Trading Scheme (ETS) (Bailey 2003: 41). While the ETS has faced extensive criticism, it provides a blueprint for national and regional schemes, and demonstrates the plausibility of a global ETS (Schreurs and Tiberghien 2007). This leadership by example has provided a regional basis for how GCC policy could be implemented at a global scale, through co-operation, cohesion and leadership. More broadly, the EU's continued faith in the UNFCCC and Kyoto Protocol is an affirmation of its commitment to multilateralism through UN mechanisms, trade and dialogue (Vogler and Stephan 2007). The EU decision to proceed with 
the Kyoto Protocol without US support was a defining moment in its external politics, and its entry into force in 2005 (following Russia's ratification) was a major victory for the EU's long term SD diplomacy.

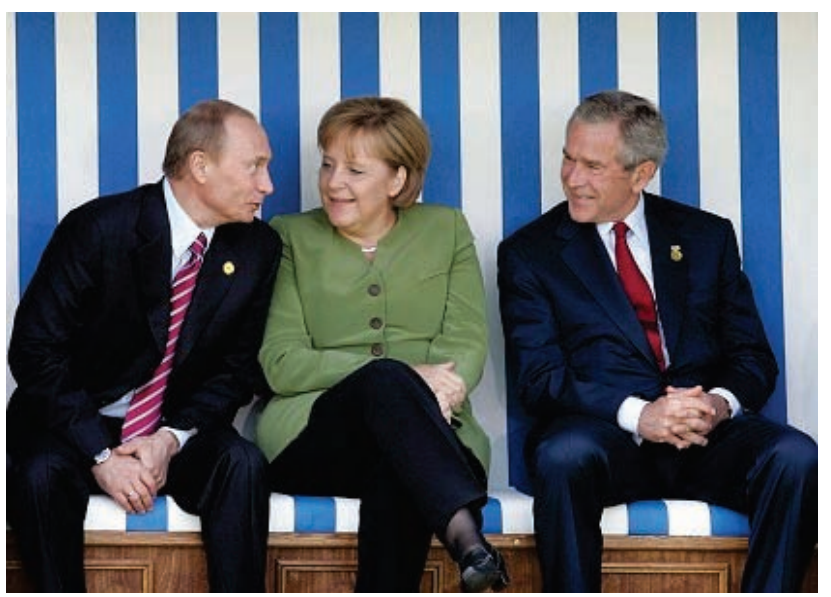

Fig. 1: Angela Merkel has emerged as a GCC policy entrepreneur, securing a G8 agreement on climate change. Source: (Spiegel Online 2007)

According to Lacasta et al (2007: 211) the EU has taken the environment into the domain of "high politics", with leaders engaging in direct diplomacy on climate change with countries outside the EU (Lacasta et al. 2007: 211; Oberthür and Roche Kelly 2008: 35). Angela Merkel has emerged as a key policy entrepreneur in gaining support for EU positions on GCC and SD (Figure 1) (Smith and Mix 2007). A major victory of her 2007 presidency of the G-8 was the launch of negotiations for a G-8 climate agreement, with leaders agreeing to "consider and adopt... the goal of achieving at least 50 per cent reduction of global emissions by 2050 , recognising that this global challenge can only be met by a global response" (Pilling and Harvey 2008). Her direct engagement with G-8 leaders laid the foundation for consensus on a Bali roadmap at the 2007 UNFCCC Conference of the Parties. In order to match this leadership with corresponding "low diplomacy", the Commission has launched a "Green Diplomacy Network" to integrate the environment and SD into all relevant areas of foreign policy (DG External Relations 2007). While Vogler (2007) and Oberthür and Roche Kelly (2008) question the effectiveness of this network, it has the potential to further cement the environment and SD into the EU's external policy identity.

\section{FUTURE DIRECTIONS}

In order to secure the integrity of sustainable development and global climate change leadership in the EU external policy identity, the EU must aim to meet its Kyoto targets. Yet even if it comes close, the EU will still have demonstrated its capacity to lead by example on GCC and SD (Schreurs and Tiberghien 2007). It is clear that the EU intends to remain a unified leader. In March 2009, EU environment ministers agreed to a binding target of a $20 \%$ reduction relative to 1990 levels by 2020 , which will increase to a $30 \%$ reduction provided other developed countries commit to making comparable reductions. But will the EU be able to maintain its position, approach and success?

A post-2012 EU agreement will expand the "EU bubble" from 15 members to 27 , with a far greater diversity in economic and technical capacity and less exposure to the sustainability discourse (Lacasta et al. 2007). This presents a challenge to cohesion and meeting mitigation targets. Should the 2007 Lisbon Treaty enter into force, the decision making process and efficacy of the EU in external relations may be greatly improved (Oberthür and Roche Kelly 2008). Article 2 (5) of the Treaty of the European Union will be updated to state that the EU shall "contribute to... the sustainable development of the earth..." internalising Europe's identity as a normative force for SD. However, many of the interest groups who tried to use their influence to "green" the treaty of Lisbon felt blocked out of the Lisbon treaty negotiation process (Vedder 2008). Such sentiment could weaken the SD discoursethreatening to make sustainability a bureaucratic ideal that loses the popular support and public participation that has given the discourse such power (Sneddon et al. 2006). However, the biggest resistance to the EU's GCC leadership and sustainability diplomacy may come from the 2008 developments in global financial markets and economies. Several EU member states have questioned whether they are capable of meeting their mitigation targets in their current economic situation, but both Yvo de Boer (UNFCCC Executive Secretary) and Ban Ki-moon (UN Secretary General) have called on all UNFCCC parties to use the current economic challenges as an opportunity to build a more sustainable economy (Copenhagen Climate Council, 2008; UN News Service, 2008). Therefore, a real test of the EU approach will be the level of unity and ambition that of Europe brings to Copenhagen in 2009, where a Post-2012 agreement 
will be negotiated in a challenging economic environment.

\section{CONCLUSION}

A loosely defined principle of sustainable development has become a relatively powerful discourse in the EU's evolving identity. The most notable manifestation of the discourse has surrounded climate change, an issue that has been approached with a level of unity and cohesion lacking in other areas of EU affairs. I have demonstrated that in many ways, European cohesion and the SD discourse have been mutually reinforcing, as the discourse reconciles the interests of different actors within the EU. The EU has "led by example" in its approach to climate change mitigation by embodying key UNFCCC principles and agreeing to ambitious GHG reduction targets. These actions support Europe's power as a normative global force.

Preventing dangerous climate change remains one of the most significant, long-term global challenges. Unity around a sustainable development discourse and success in meeting mitigation targets are critical to maintaining EU legitimacy as a global sustainability leader, and, in turn, securing a sustainable global solution to climate change. However, the long term sustainability of the European position and the EU's aggressive mitigation targets is questionable. In the face of the challenges caused by expansion and economic concern, the EU must maintain its unity and ambition for a sustainable future.

\section{ACKNOWLEDGMENTS}

This article was originally prepared as an essay for the 2008 International Alliance of Research Universities Global Summer Program at Oxford University. I am very grateful for the assistance of Dr. Rosie Cooney as I adapted the essay for publication following my return to ANU. Rosie's continued patience and support during the supervision of this, and other publications, has been fantastic. I would also like to thank Elizabeth Humphries sincerely for her dedicated support and encouragement during the editing process.

\section{REFERENCES}

Bailey, I., 2003. New environmental policy instruments in the European Union, Ashgate, Aldershot.

Bainbridge, T., 2002. The Penguin Companion to the European Union, Penguin, London.

Copenhagen Climate Council, 2008. Financial Crisis, EU Debates Make Copenagen Deal More Difficult, 3rd November 2008. Available at:

$<$ http:/www.copenhagenclimatecouncil.com/getinformed/points-of-view/financial-crisis-eu-debatesmake-copenhagen-deal-more-difficult-says-unfccc-s-deboer.html> (accessed 19 December 2008).

Delreux, T., 2006. The European Union in international environmental negotiations: a legal perspective on the internal decision-making process, International Environmental Agreements, 6(3): 231-248.

DG External Relations, 2007. The EU Green Diplomacy Network - Integrating environment into foreign policy, Available at:

$<$ http://ec.europa.eu/external_relations/env/gdn/index.htm $>$ (accessed 13 July 2008).

Dinan, D., 2005. Ever Closer Union, Lynne Rienner Publishers, Boulder, CO.
Dryzek, J., 2005. The politics of the earth: environmental discourses, Oxford University Press, New York.

European Communities, 2008. The EU in the World, Available at:

$<$ http://europa.eu/lisbon_treaty/glance/external_relations/i ndex_en.htm $>$ (accessed 18 December 2008).

Falkner, R., 2006. The European Union as a 'Green Normative Power'? EU Leadership in International Biotechnology Regulation. Center for European Studies Working Paper Series \#140, Available at:

$<$ https://www.lse.ac.uk/collections/geographyAndEnviron ment/CEPG/Publications/Falkner_EuropeanUnionNormat ive_2006.pdf> (accessed 15 July 2008).

Huber, M., 1997. Leadership in the European climate policy: innovative policy making in policy networks, In The innovation of EU environment policy(Eds, Liefferink, D. and Andersen, M. S.) Scandinavian University Press, Copenhagen.

Kronsell, A., 1997. Policy innovation in the garbage can: the EU's Fifth Environmental Action program, In The innovation of EU environmental policy(Eds, Liefferink, D. 
and Andersen, M. S.) Scandinavian University Press, Copenhagen.

Lacasta, N., Dessai, S., Kracht, E. and Vincent, K., 2007. Articulating a Consensus: the EU's position on climate change, In Europe and Global Climate Change (Ed, Harris, P. G.) Edward Elgar, Cheltenham.

Oberthür, S. and Roche Kelly, C., 2008. EU Leadership in International Climate Policy: Achievements and Challenges, International Spectator, 43(3): 35-50.

Parry, M. L., Canziani, O. F., Palutikof, J. P. and CoAuthors, 2007. Technical Summary, In Climate Change 2007: Impacts, Adaptation and Vulnerability.

Contribution of Working Group II to the Fourth Assessment Report of the Integovernmental Panel on Climate Change. (Eds, Parry, M. L., Canziani, O. F., Palutikof, J. P., van der Linden, P. J. and Hanson, C. E.) Cambridge University Press, Cambridge.

Peterson, J., 2008. The EU as a global actor, In The European Union: How does it work (Eds, Bomberg, E., Peterson, J. and Stubb, A.) Oxford University Press, Oxford.

Pilling, D. and Harvey, F., 2008. Bush agrees to target on greenhouse gases, Available at:

$<\mathrm{http}: / / w w w . f t . c o m / c m s / s / 0 / 6 b 362 f 44-4 c 9 c-11$ dd-96bb000077b07658.html $>$ (accessed 16 July 2008).

Sbragia, A. and Stolfi, F., 2008. Key Policies, In The European Union: How Does it Work (Eds, Bomberg, E., Peterson, J. and Stubb, A.) Oxford University Press, Oxford.

Schreurs, M. A. and Tiberghien, Y., 2007. Multi-Level Reinforcement: Explaining European Union Leadership in Climate Change Mitigation, Global Environmental Politics, 7(4): 19-45.

Smith, J. and Mix, D., 2007. The Transatlantic Climate Change Challenge, Washington Quarterly, 31(139-153).
Sneddon, C., Howarth, R. B. and Norgaard, R. B., 2006. Sustainable development in a post-Brundtland world, Ecological Economics, 57(2): 253-268.

Spiegel Online, 2007. "Miss World" Merkel kept G8 men in line, Available at:

$<$ http://www.spiegel.de/fotostrecke/0,5538,22268,00.html

$>$ (accessed 16 July 2008).

TNS Opinion and Social, 2008. Special Eurobaromter 300: Europeans' attitudes towards climate change,

Directorate-General Communications, European Commission. Available at: http://ec.europa.eu/public_opinion/archives/ebs/ebs_300_ full_en.pdf (accessed 16 December 2008).

UN News Service, 2008. Secretary-General calls or 'Green New Deal' at UN climate change talks, 11th December. Available at:

$<$ http://www.un.org/apps/news/story.asp?NewsID=29264 $\& \mathrm{Cr}=$ Climate $\& \mathrm{Cr} 1=>$ (accessed 19 December 2008).

United Nations Statistics Division, 2007. Carbon dioxide emissions (CO2), thousand metric tons of $\mathrm{CO} 2$, Available at:

$<$ http://mdgs.un.org/unsd/mdg/SeriesDetail.aspx?srid=74 $9 \&$ crid $=>$ (accessed 15 July 2008).

Vedder, H., 2008. The Treaty of Lisbon and European Environmental Policy, Social Science Research Network. Available at:

http://papers.ssrn.com/sol3/Delivery.cfm/SSRN_ID13101 90_code894969.pdf?abstractid $=1310190 \&$ mirid $=1$ (accessed 18 December 2008).

Vogler, J. and Bretherton, C., 2006. The European Union as a Protagonist to the United States on Climate Change, International Studies Perspectives, 7: 1-22.

Vogler, J. and Stephan, H. R., 2007. The European Union in global environmental governance: Leadership in the making?. International Environmental Agreements, 7: 389-413. 